\title{
Pengaruh Komposisi Pada Minyak Telon Terhadap Uji Indeks Bias Dengan Menggunakan Refraktometer Tipe Way Abbe
}

\author{
Frengky Hutama Putra Solarbesain dan Isti Pudjihastuti* \\ Program Studi Teknik Kimia, Departemen Teknologi Industri, Sekolah Vokasi, Universitas Diponegoro \\ Jl. Prof. Soedarto, Tembalang, Kota Semarang, Jawa Tengah 50275, Indonesia \\ Email : frengkyd69@gmail.com
}

\begin{abstract}
Abstrak
Penelitian ini bertujuan untuk mengetahui indeks bias Minyak Ttelon dengan komposisi yang berbeda-beda. Pembuatan minyak telon dari campuran kelapa dan minyak atsiri (minyak adas dan kayu putih) dengan variasi komposisi Minyak kayu putih : minyak kelapa : minyak adas. Hasil di uji indeks biasnya menggunakan refraktometer dan organoleptik. Hasil indeks bias yang didapat sampel Pertama dengan komposisi minyak telon (20:20:15) yaitu 1,4510 D, Sampel kedua dengan komposisi minyak telon (15:10:20) yaitu 1,4465 D, dan sampel ketiga dengan komposisi minyak telon (10:15:20) yaitu 1,4468 D. Dari hasil uji organoleptik di dapatkan minyak telon yang lebih disukai yaitu pada sampel pertama dengan komposisi minyak telon (20:20:15), dan minyak telon yang kurang disukai yaitu pada sampel ketiga dengan komposisi minyak telon (10:15:20). Pada Uji Organoleptik sampel minyak telon yang disukai yaitu sampel satu lebih dengan komposisi minyak kayu putih $20 \mathrm{ml}$, minyak kelapa $20 \mathrm{ml}$ dan minyak adas $15 \mathrm{ml}$ lebih disukai dimbandingkan yang lainnya. Dari segi aroma khas minyak telon lebih kuat tercium, untuk warnanya bening dan pada saat dioleskan pada kulit terasa hangat.
\end{abstract}

Kata Kunci : Minyak atsiri, Pencampuran, Indeks Bias dan organoleptik

\section{Abstract \\ Effect of Composition on Telon Oil on Bias Index Test Using Abbe Way Type Refractometer}

Research aims to find the refractive index of Ttelon Oil with different composition. The manufacture of telon oil from coconut and essential oil mixture (fennel oil and eucalyptus) with variation of composition of eucalyptus oil: coconut oil: fennel oil. Results in the refractive index test using refractometer and organoleptic. The result of refractive index obtained First sample with the composition of oil telon (20:20:15) that is $1.4510 \mathrm{D}$, second sample with the composition of oil telon (15:10:20) that is $1.4465 \mathrm{D}$, and the third sample with the composition of oil telon (10:15:20) that is $1.4468 \mathrm{D}$. From the results of organoleptic test in obtain the preferred telon oil that is in the first sample with the composition of telon oil (20:20:15), and the oil is less favored telon that is in the third sample with the composition of oil telon (10:15:20). In the preferred Organoleptic Test the preferred sample of telon oil is one more sample with a $20 \mathrm{ml}$ eucalyptus oil composition, $20 \mathrm{ml}$ coconut oil and $15 \mathrm{ml}$ fennel oil preferably compared to the others. In terms of distinctive aroma of telon oil more strong smell, for the color is clear and at the time applied to the skin was warm.

Keywords: Essential Oil, Mixing, Refractive Index and Organoleptic

\section{PENDAHULUAN}

Minyak atsiri dikenal juga dengan nama minyak eteris atau minyak terbang (ethereal oil, volatile oil) dihasilkan oleh tumbuhan. Minyak tersebut mudah menguap pada suhu kamar tanpa mengalami dekomposisi, mempunyai rasa getir, berbau wangi sesuai dengan bau tumbuhan 
penghasilnya, umumnya larut dalam pelarut organik dan tidak larut dalam air (Ketaren, 1985). Proses produksi minyak atsiri dapat ditempuh melalui 3 cara, yaitu: pengempaan (pressing), ekstraksi menggunakan pelarut, (solvent extraction) dan penyulingan (distillation). (Kardinan, 2005)

Minyak telon adalah campuran 3 macam minyak. Kata telon berasal dari Bahasa Jawa yang berarti telu atau tiga. Minyak telon merupakan paduan dari minyak adas, minyak kayu putih (Oleum Cajuputi) dan minyak kelapa (Oleum Cocos). tertentu. Ketiganya mempunyai fungsi yang berbeda dan khasiatnya bersinergi satu dengan yang lain.

Buah adas mengandung 2-6\% minyak atsiri (terdiri dari 50-70\% transanetol, lebih kurang 20\% cis-anetol) $0,3 \%$; $15-24 \%$ fenkon (fenkon berasa pahit dan mempunyai aroma seperti kamfer). Di samping itu buah adas mengandung pula metilkavikol 4-7\%, anisaldehid (suatu hasil oksidasi anetol), beberapa senyawa terpenoid hidrokarbon (pinen, felandren dan limonen), funikulin, dan terpineol. Selain kandungan minyak atsiri, dalam buah adas terdapat pula funikulosida, suatu stilbeneglikosida, minyak lemak, protein, asam-asam organik dan flavonoid (Sudarsono et al., 2002).

Minyak kayu putih (cajuput oil, oleummelaleuca-cajeputi, atau oleum cajeputi) dihasilkan dari hasil penyulingan daun dan ranting kayu putih ( $M$. leucadendra). Minyak ini mengandung terutama eukaliptol (1,8-cineol) (komponen paling banyak, sekitar 60\%), $\alpha$-terpineol dan ester asetatnya, $\alpha$-pinen, dan limonen.

Virgin coconut oil (VCO) yaitu minyak yang diperoleh dari daging buah kelapa tua yang segar dan diproses dengan diperas, dengan atau tanpa penambahan air, tanpa pemanasan atau pemanasan tidak lebih dari $60^{\circ} \mathrm{C}$ dan aman dikonsumsi manusia. (SNI, 2008). Daging buah kelapa segar sebagai bahan baku VCO memiliki kandungan minyak $34,7 \%$, protein $3,8 \%$, air $46,9 \%$ dan karbohidrat $14,6 \%$, sedangkan komponen VCO sendiri berupa asam lemak jenuh sekitar $90 \%$ dan asam lemak tak jenuhsekitar 10\%. Asam lemak jenuh VCO didominasi oleh asam laurat. VCO mengandung $\pm 51,24 \%$ asam laurat dan sekitar 7,91\% asam kaprilat. Keduanya merupakan asam lemak rantai sedang yang biasa disebut
Medium Chain Fatty Acid (MCFA) (Sutarmi dan Hartin, 2005)

Komposisi masing-masing minyak dalam minyak telon (minyak kelapa : minyak adas : minyak kayu putih : minyak kelapa) adalah 3:3:4. Minyak kelapa berfungsi sebagai minyak pembawa atau pelarut (carrier oil). Saat ini beberapa produsen minyak telon ada yang memproduksi minyak telon dengan komposisi yang berbeda, misalkan 1:1:3, ataupun menambah minyak lain sebagai campuran, seperti minyak esensial lavender, bahkan ada yang mengganti minyak kelapa dengan minyak Zaitun (olive oil). Namun tentunya kalau sudah ditambahkan minyak lain diluar formula yang telah dikenal turun temurun manfaatnya akan berbeda dan aroma khas minyak telon tak tercium lagi. (Rusli, 2010).

Refraktometer atau refractometer adalah sebuah alat yang biasa digunakan untuk mengukur Indeks Bias bahan atau zat terlarut. Misalnya gula ("Brix"), garam ("Baume"), protein, dsb. Metode kerja dari refraktometer ini dengan memanfaatkan teori refraksi cahaya. Alat Refraktometer ini ditemukan oleh Dr. Ernest Abbe, yaitu seorang ilmuan asal German pada awal abad 20 (Schulze et al., 2015).

Refraktometer Abbe adalah refraktometer untuk mengukur indeks bias cairan, padatan dalam cairan dengan indeks bias dari 1,300 sampai 1,700 dan persentase padatan 0 sampai $95 \%$, alat untuk menentukan indeks bias minyak, lemak, gelas optis, larutan gula, dan sebagainnya, indeks bias antara 1,300 dan 1,700 dapat dibaca langsung dengan ketelitian sampai 0,001 dan dapat diperkirakan sampai dengan 0,0002 dari gelas skala di dalam (Mulyono, 1997). Pengukurannya didasarkan pada prinsip bahwa cahaya yang masuk melewati prisma-cahaya hanya bisa melewati bidang batas antara cairandan prisma kerja dengan suatu sudut yang terletak dalam batas-batas tertentu yang ditentukan oleh sudut batas antara cairan dan alas (Green et al., 2007).

Indeks Bias merupakan perbandingan laju cahaya dalam ruang hampa $\mathrm{c}$ terhadap laju cahaya tersebut dalam medium $v$, maka besarnya indeks bias dalam medium apapun selain udara, besarnya selalu lebih besar dari satu. Secara matematis (Parmitasari dan Hidayanto, 2013) 
Penelitian tentang pembuatan minyak telon yang telah dilakukan (Nahar, 2009). Namun demikian, penelitian tersebut dilakukan hanya untuk analisa Asam Lemak Bebas dan Organoleptik. Pada penelitian ini akan membahas pengaruh komposisi minyak telon pada indeks bias dan organoleptik

\section{METODOLOGI}

Penelitian tentang pengaruh komposisi minyak telon pada uji indeks bias dilakukan secara bertahap meliputi: tahap perlakuan awal dan tahap analisa. Pada tahap perlakuan awal meliputi persiapan bahan baku, pencucian, dan pemotongan sampel sesuai variabel. Bahan baku yang digunakan dalam penelitian ini adalah kunyit orange dan kunyit putih. Alat utama yang digunakan adalah Refraktometer tipe WAY ABBE, serta variabel minyak kayu putih, minyak kelapa dan minyak adas yaitu variabel 1 (20ml:20ml:15ml), Variabel 2 (15ml:10ml:20ml) dan Variabel 3 (10ml:20ml:15ml)

Tahap analisa produk yang dilakukan meliputi analisa Indeks Bias serta analisa organoleptik. Analisa Indeks bias bertujuan untuk mengetahui perbandingan kecepatan cahaya dalam udara dengan kecepatan cahaya dalam zat tersebut. Analisa yang kedua yaitu analisa organoleptik merupakan analisa dengan penilaian indera, yang meliputi aroma, warna, dan dioleskan pada kulit. Uji organoleptik memiliki relevansi yang tinggi dengan mutu produk karena berhubungan langsung dengan selera konsumen.

\section{HASIL DAN PEMBAHASAN}

Sampel pertama dengan komposisi minyak kayu putih $20 \mathrm{ml}$, minyak kelapa $20 \mathrm{ml}$ dan minyak adas $15 \mathrm{ml}$ didapatkan indeks bias 1,4510 D. Kemudian pada sampel yang kedua dengan komposisi minyak kayu putih $15 \mathrm{ml}$, minyak kelapa $10 \mathrm{ml}$ dan minyak adas $20 \mathrm{ml}$ diperoleh indeks bias 1,4465 D. Sedangkan pada sampel ketiga dengan komposisi minyak kayu putih 10 $\mathrm{ml}$, minyak kelapa $20 \mathrm{ml}$ dan minyak adas $15 \mathrm{ml}$ diperoleh indeks bias 1,4468 D (Tabel 1).

Nilai indeks bias masih masuk dalam standar SNI yang mensyaratkan nilai indeks bias pada kisaran 1,45 - 1,47. Arnita (2011) menyebutkan bahwa semakin padat suatu benda maka akan semakin besar pula nilai indeks biasnya.Dari ketiga sampel didapatkan indeks bias yang berbeda-beda hal ini dikarenakan jumlah campuran dari minyak kayu putih, minyak kelapa dan minyak adas yang berbeda-beda.

Pada penelitian yang dilakukan oleh Nahar (2009) yaitu pembuatan minyak telon dari campuran VCO dan minyak atsiri (minyak pala dan kayu putih) dengan variasi komposisi VCO : minyak pala : minyak kayu putih. Pada sampel 1 Komosisi minyak telon yang digunakan yaitu $40 \mathrm{ml} \mathrm{VCO}, 20 \mathrm{ml}$ Minyak pala, dan $40 \mathrm{ml}$ minyak kayu putih. Sampel 2 digunakan komposisi $50 \mathrm{ml}$ $\mathrm{VCO}, 20 \mathrm{ml}$ minyak pala, $30 \mathrm{ml}$ minyak kayu putih . Sampel 3 digunakan komposisi $50 \mathrm{ml}$ VCO, $40 \mathrm{ml}$ minyak pala, $10 \mathrm{ml}$ minyak kayu putih. Sampel disimpan selama 0, 1 dan 3 bulan dan diuji nilai ALB dan organoleptik terhadap aroma dan warna.

Dari hasil uji organoleptik di dapatkan aroma minyak telon yang lebih banyak disukai pada waktu penyimpanan 3 bulan dengan komposisi minyak telon (50:40:10), dan warna minyak telon yang lebih banyak disukai pada waktu penyimpanan 1 bulan dengan komposisi minyak telon (50:20:30). Hal ini karena minyak telon yang dihasilkan hamper sesuai dengan produk yang dijual dipasaran baik dari segi aroma maupun warna dari minyak telon itu sendiri.

Produk Minyak telon yang paling disukai konsumen dipasaran memiliki komposisi Olemu lavandulae (Minyak Lavender) $30 \mathrm{mg}$, Oleum geranii (minyak Greanium) 30 mg, Oleum cajuputi (Minyak Kayu Putih) 420 mg, Oleum anisi (Minyak Adas Manis) 100 mg, dan Oleum cocos (Minyak Kelapa) $420 \mathrm{mg}$. Indeks bias yang di dapat yaitu 1,4594 .

Jika dibandingkan dengan minyak telon yang disukai dipasaran dengan hasil praktikum dari segi komposisi terdapat perbedaan bahan yaitu pada minyak telon yang di sukai dipasaran menambahkan minyak lavender dan minyak geranium yang berfungsi melindungi konsumen dari gigitan nyamuk. Sedangkan dari indeks biasnya hasil praktikum hampir mendekati indeks bias dari minyak telon yang disukai konsumen dipasaran.

Berdasarkan pelelitiasn Minyak telon yang telah dibuat kemudian dilakukan uji organoleptik 
dengan 3 panelis. Kriteria dari uji organoleptic yaitu aroma, warna dan dioleskan pada kulit. Pada sampel pertama (Tabel 2) dengan komposisi minyak telon yaitu minyak kayu putih $20 \mathrm{ml}$, minyak kelapa $20 \mathrm{ml}$ dan minyak adas $15 \mathrm{ml}$ panelis pertama memberikan nilai 4,4 dan 4 . Sedangkan panelis kedua memberikan nilai untuk sampel pertama yaitu 4, 4 dan 4. Kemudian panelis ketiga memberikan nilai 4, 4 dan 4 . Selanjutnya sampel yang kedua (Tabel 3) dengan komposisi minyak kayu putih $15 \mathrm{ml}$, minyak kelapa $10 \mathrm{ml}$ dan minyak adas $20 \mathrm{ml}$, panelis pertama memberikan nilai 4,4 dan 3. Sedangkan panelis kedua memberikan nilai untuk sampel pertama yaitu 4, 4 dan 3. Kemudian panelis ketiga memberikan nilai 5, 4 dan 3.Dan untuk sampel yang ketiga (Tabel 4) dengan komposisi minyak kayu putih $10 \mathrm{ml}$, minyak kelapa $20 \mathrm{ml}$ dan minyak adas $15 \mathrm{ml}$ penilaian menurut panelis pertama yaitu 3,3 dan 3. Sedangkan panelis kedua memberikan nilai untuk sampel pertama yaitu 4, 3 dan 4. Kemudian panelis ketiga memberikan nilai 4, 3 dan 3.

Berdasarkan Gambar diatas yang menyatakan tingkat kesukaan dari ketiga sampel minyak telon yang sudah diuji organoleptik oleh ketiga panelis. Dapat dilihat bahwa sampel satu lebih dengan komposisi minyak kayu putih $20 \mathrm{ml}$,

Tabel 1. Uji Indeks Bias Minyak Telon

\begin{tabular}{ccccc}
\hline \multirow{2}{*}{ Sampel } & \multicolumn{3}{c}{ Komposisi } & \\
\cline { 2 - 4 } & $\begin{array}{c}\text { Minyak Kayu Putih } \\
(\mathrm{ml})\end{array}$ & $\begin{array}{c}\text { Minyak Kelapa }(\mathrm{ml}) \\
\text { Mnndeks Bias (D) }\end{array}$ & Minyak Adas (ml) & \\
\hline 1 & 20 & 20 & 15 & 1,4510 \\
2 & 15 & 10 & 20 & 1,4465 \\
3 & 10 & 20 & 15 & 1,4468 \\
\hline
\end{tabular}

Tabel 2. Hasil Uji Organoleptik Sampel 1

\begin{tabular}{cccc}
\hline \multirow{2}{*}{ Panelis } & \multicolumn{4}{c}{ Uji Organoleptik } \\
\cline { 2 - 4 } & Aroma & Warna & Dioleskan pada kulit \\
\hline 1 & 4 & 4 & 4 \\
2 & 4 & 4 & 4 \\
3 & 4 & 4 & 4 \\
\hline
\end{tabular}

Tabel 3. Hasil Uji Organoleptik Sampel 2

\begin{tabular}{cccc}
\hline \multirow{2}{*}{ Panelis } & \multicolumn{4}{c}{ Uji Organoleptik } \\
\cline { 2 - 4 } & Aroma & Warna & Dioleskan pada kulit \\
\hline 1 & 4 & 4 & 3 \\
2 & 4 & 4 & 3 \\
3 & 5 & 4 & 3 \\
\hline
\end{tabular}

Tabel 4. Hasil Uji Organoleptik Sampel 3

\begin{tabular}{cccc}
\hline \multirow{2}{*}{ Panelis } & \multicolumn{3}{c}{ Uji Organoleptik } \\
\cline { 2 - 4 } & Aroma & Warna & Dioleskan pada kulit \\
\hline 1 & 3 & 3 & 3 \\
2 & 4 & 3 & 4 \\
3 & 4 & 3 & 3 \\
\hline
\end{tabular}


minyak kelapa $20 \mathrm{ml}$ dan minyak adas $15 \mathrm{ml}$ lebih disukai dimbandingkan yang lainnya. Dari segi aroma khas minyak telon lebih kuat tercium, untuk warnanya bening dan pada saat dioleskan pada kulit terasa hangat. Sedangkan yang memiliki tingkat kesukaan yang rendah yaitu sampel ketiga karena dari segi warna sangat keruh dan terjadi 2 lapisan. Terjadi 2 lapisan karena Dan pada saat dioleskan di kulit tidak terlalu hangat hal ini dikarenakan komposisi minyak adas dan minyak kayu putih yang sedikit. Rasa hangat yang ditimbulkan ini dikarenakan terdapat kandungan 1,8 sineol pada minyak kayu putih (Efruan et al., 2015). Dan dari segi aroma, aroma dari minyak kelapa lebih mendominasi karena minyak kelapa yang digunakan lebih banyak.

\section{KESIMPULAN}

Berdasarkan hasil percobaan yang telah dilakukan maka dapat disimpulkan bahwa minyak telon di buat dengan bahan utama minyak kayu putih, minyak kelapa dan minyak adas yang berkhasiat mencegah, dan mengobati perut kembung serta memberikan rasa hangat terutama pada bayi. Pada pengujian indeks bias menggunakan refraktometer didapatkan indeks bias pata tiap sampel yaitu sampel Pertama dengan komposisi minyak telon (20:20:15) yaitu 1,4510 D, Sampel kedua dengan komposisi minyak telon (15:10:20) yaitu 1,4465 $D$, dan sampel ketiga dengan komposisi minyak telon $(10: 15: 20)$ yaitu 1,4468 D. Pada Uji Organoleptik sampel minyak telon yang disukai yaitu sampel satu lebih dengan komposisi minyak kayu putih 20 $\mathrm{ml}$, minyak kelapa $20 \mathrm{ml}$ dan minyak adas $15 \mathrm{ml}$ lebih disukai dimbandingkan yang lainnya. Dari segi aroma khas minyak telon lebih kuat tercium, untuk warnanya bening dan pada saat dioleskan pada kulit terasa hangat.

\section{DAFTAR PUSTAKA}

Arnita, P. 2011. Pengaruh varietas dan kerapatan daun kayu putih (Melaleuca leucadendron Linn.) dalam ketel terhadap rendemen dan mutu minyak kayu putih. Skripsi. Bogor: Departemen Hasil Hutan Institut Pertanian.

Efruan, G.K., Martosupono, M. \& Rondonuwu, F.S., 2015. Identifikasi Kandungan Senyawa $\alpha-$
Pinene dalam Minyak Kayu Putih dengan Menggunakan Near Infrared Spectroscopy. Prosiding Seminar Nasional Sains dan Teknologi. Pp 1-6

Green, M.D., Nettey, H., Rojas, O.V., Pamanivong, C., Khounsaknalath, L., Ortiz, M.G., Newton, P.N., Fernández, F.M., Vongsack, L. \& Manolin, O., 2007. Use of refractometry and colorimetry as field methods to rapidly assess antimalarial drug quality. Journal of pharmaceutical and biomedical analysis, 43(1):105-110.

Kardinan, A. 2005. Tanaman Penghasil Minyak Atsiri. AgroMedia,

Ketaren, S. 1986. Pengantar Teknologi Minyak dan Lemak Pangan. Cetakan Pertama. Jakarta : UI-Press.

Mulyono. 1997. Kamus Pintar Kimia. Jakarta: Erlangga

Nahar. 2009. Pembuatan Minyak Telon Dari Campuran Minyak Atsiri. Jurnal Sains dan Teknologi Reaksi 7(1):

Parmitasari, P. \& Hidayanto, E., 2013. Analisis Korelasi Indeks Bias dengan Konsentrasi Sukrosa Beberapa Jenis Madu menggunakan Portable Brix Meter. Youngster Physics Journal, 2(4):191-198.

Rusli, M.S., 2010. Sukses memproduksi minyak atsiri. AgroMedia.

Schulze, M., Rüdiger, K., Jung, M. \& Grossfeld, R., 2015. Use of refractometry as a new management tool in AI boar centers for quality assurance of extender preparations. Animal reproduction science, 152:77-82.

Standar Nasional Indonesia. 2008. Minyak Kelapa Virgin (VCO). Jakarta : Badan Standarisasi Nasional

Sudarsono, P.N., Gunawan, D., Wahyuono, S. \& Donatus, I.A., 2002. Tumbuhan Obat II (Hasil penelitian, Sifat-sifat dan Penggunaan). PPOT UGM, Yogyakarta. 89-90

Sutarmi \& Rozaline, H., 2005. Taklukkan Penyakit dengan VCO Virgin Coconut Oil. Jakarta: Penebar Swadaya. 